NASA Technical Memorandum 107087

\title{
Effects of Thermal Treatment on Tensile Creep and Stress-Rupture Behavior of Hi-Nicalon SiC Fibers
}

H.M. Yun, J.C. Goldsby, and J.A. DiCarlo

Lewis Research Center

Cleveland, Ohio

Prepared for the

19th Annual Conference on Composites, Advanced Ceramics,

Materials and Structures

sponsored by the American Ceramic Society

Cocoa Beach, Florida, January 8-15, 1995

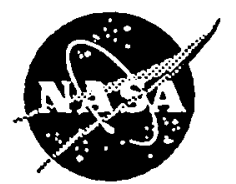

National Aeronautics and

Space Administration

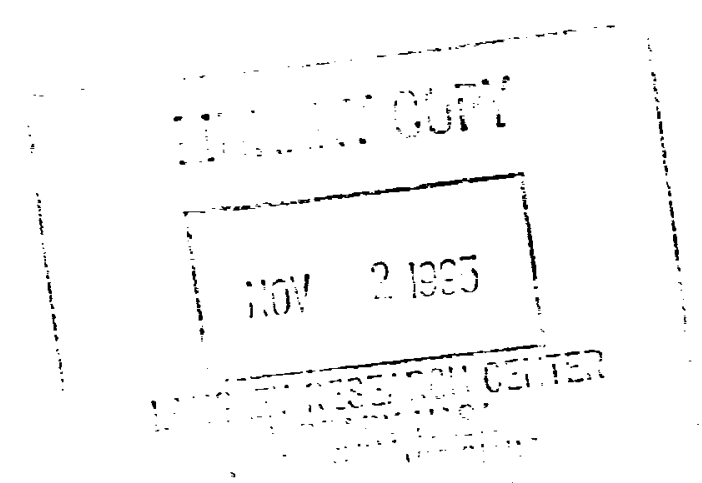




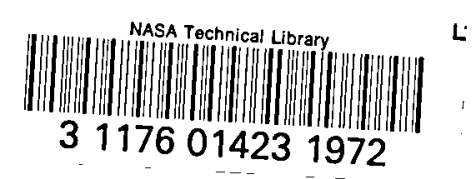

EFFECTS OF THERMAL TREATMENT ON TENSILE CREEP AND
STRESS-RUPTURE BEHAVIOR OF HI-NICALON SIC FIBERS

H.M.YUN, J.C.GOLDSBY, AND J.A.DICARLO

NASA LEWIS RESEARCH CENTER

CLEVELAND, OHIO 44135

\section{ABSTRACT}

Tensile creep and stress-rupture studies were conducted on Hi-Nicalon SiC fibers at 1200 and $1400{ }^{\circ} \mathrm{C}$ in argon and air. Examined were as-received fibers as well as fibers annealed from 1400 to $1800^{\circ} \mathrm{C}$ for 1 hour in argon before testing. The creep and rupture results for these annealed fibers were compared to those of the as-received fibers to determine the effects of annealing temperature, test temperature, and test environment. Argon anneals up to $1500^{\circ} \mathrm{C}$ degrade room temperature strength of Hi-Nicalon fibers, but improve fiber creep resistance in argon or air by as much as $100 \%$ with no significant degradation in rupture strength. Argon anneals above $1500^{\circ} \mathrm{C}$ continue to improve fiber creep resistance when tested in argon, but significantly degrade creep resistance and rupture strength when tested in air. Decrease in creep resistance in air is greater at $1200^{\circ} \mathrm{C}$ than at $1400^{\circ} \mathrm{C}$. Mechanisms are suggested for the observed behavior.

\section{INTRODUCTION}

Hi-Nicalon fiber is currently of high technical interest for reinforcement of ceramic matrix composites (CMC) because of its small diameter high room temperature strength and excellent high temperature strength retention after thermal exposure [1]. In contrast to ceramic grade Nicalon, the Hi-Nicalon fiber contains a low content of oxygen (below $0.5 \mathrm{wt}$. \%) which minimizes the strength degradation problem relating to decomposition of silicon oxycarbide. As-produced Hi-Nicalon fibers are also reported to have good rupture and creep strength [2,3].

\footnotetext{
*NASA Resident Research Associate at Lewis Research Center.
} 
Since CMC may be fabricated and used above the maximum processing temperature for the polymer derived Hi-Nicalon fibers $\left(-1300^{\circ} \mathrm{C}\right)$, there is a need to understand the effects of these thermal excursions on the fiber key structural properties. Annealed Hi-Nicalon fibers are reported to decrease in room temperature strength [4], but little is known concerning annealing effects on fiber creep strength and rupture strength. Thus the objective of this study was to obtain an understanding of how CMC fabrication and use temperatures above $1300{ }^{\circ} \mathrm{C}$ can affect Hi-Nicalon tensile strength, creep strength, and rupture strength in argon and air test environments.

\section{EXPERIMENTAL PROCEDURE}

As-produced Hi-Nicalon fibers contain very fine $\mathrm{SiC}$ grains of about $4 \mathrm{~nm}$ in size, a very low content of oxygen ( $0.5 \mathrm{wt} . \%)$, but a large volume fraction of free carbon ( $-35 \mathrm{~mol} . \%)$. The maximum process temperature is $-1300^{\circ} \mathrm{C}$, and the room temperature strength is about $2800 \mathrm{MPa}$. These and other properties of as-produced fibers are shown in Table $1[3,4]$.

Table I. PROPERTIES OF Hi-NICALON SiC FIBERS

\begin{tabular}{|c|c|}
\hline Manufacturer & Nippon Carbon \\
\hline \# of Filaments(fil./yarn) & 500 \\
\hline $\begin{array}{l}\text { Composition } \\
\text { (mol.\%) }\end{array}$ & $\begin{array}{l}\sim 65 \% \text { B SiC + } \\
\sim 35 \% \text {. }\end{array}$ \\
\hline Impurity & $\sim 0.5 \% 0$ \\
\hline $\begin{array}{c}\text { Max.Processing } \\
\text { Temp. } \\
\end{array}$ & $\sim 1300 \mathrm{C}$ \\
\hline $\begin{array}{c}\text { Avg. Grain Size } \\
\text { (nm) }\end{array}$ & 4 \\
\hline Avg. Diampter & 14 \\
\hline Density $\left(\mathrm{g} / \mathrm{cm}^{3}\right)$ & 2.7 \\
\hline $\begin{array}{l}\text { Elastic Modulus } \\
\text { at RT (GPa) }\end{array}$ & $\sim 270$ \\
\hline $\begin{array}{r}\text { Tensile Strength } \\
\text { at RT (MPa) }\end{array}$ & 2800 \\
\hline
\end{tabular}

To determine the effects of thermal exposure above their maximum processing temperature, as-produced fibers were annealed at 1400 ; 1500,1600 , and $1800^{\circ} \mathrm{C}$ for $1 \mathrm{hr}$ in a graphite heating element furnace located in a chamber filled with high purity argon at 
- 1.4 atm. pressure. The tensile strengths of as-produced and annealed fibers were measured at $-25 \mathrm{~mm}$ gauge length using a commercial test frame. The tensile creep and stress-rupture strength of as-produced and annealed fibers were measured at 1200 and $1400{ }^{\circ} \mathrm{C}$ in air ( $\mathrm{MoSi}_{2}$ heating element) and argon (graphite heating element) at gauge lengths of -25 and $112 \mathrm{~mm}$, respectively. The single fiber specimens were mounted outside the furnace heating element using paper tab grips and epoxy glue. Constant stress was provided by dead weight loading in a single fiber furnace for air [5] and in a multifiber Creep Testing Frame for argon, as shown in Fig. 1. A hot grip method [6] was also utilized for air testing and the creep strains were found to be in fairly good agreement with the cold grip method. The fiber length change was monitored by an LVDT.

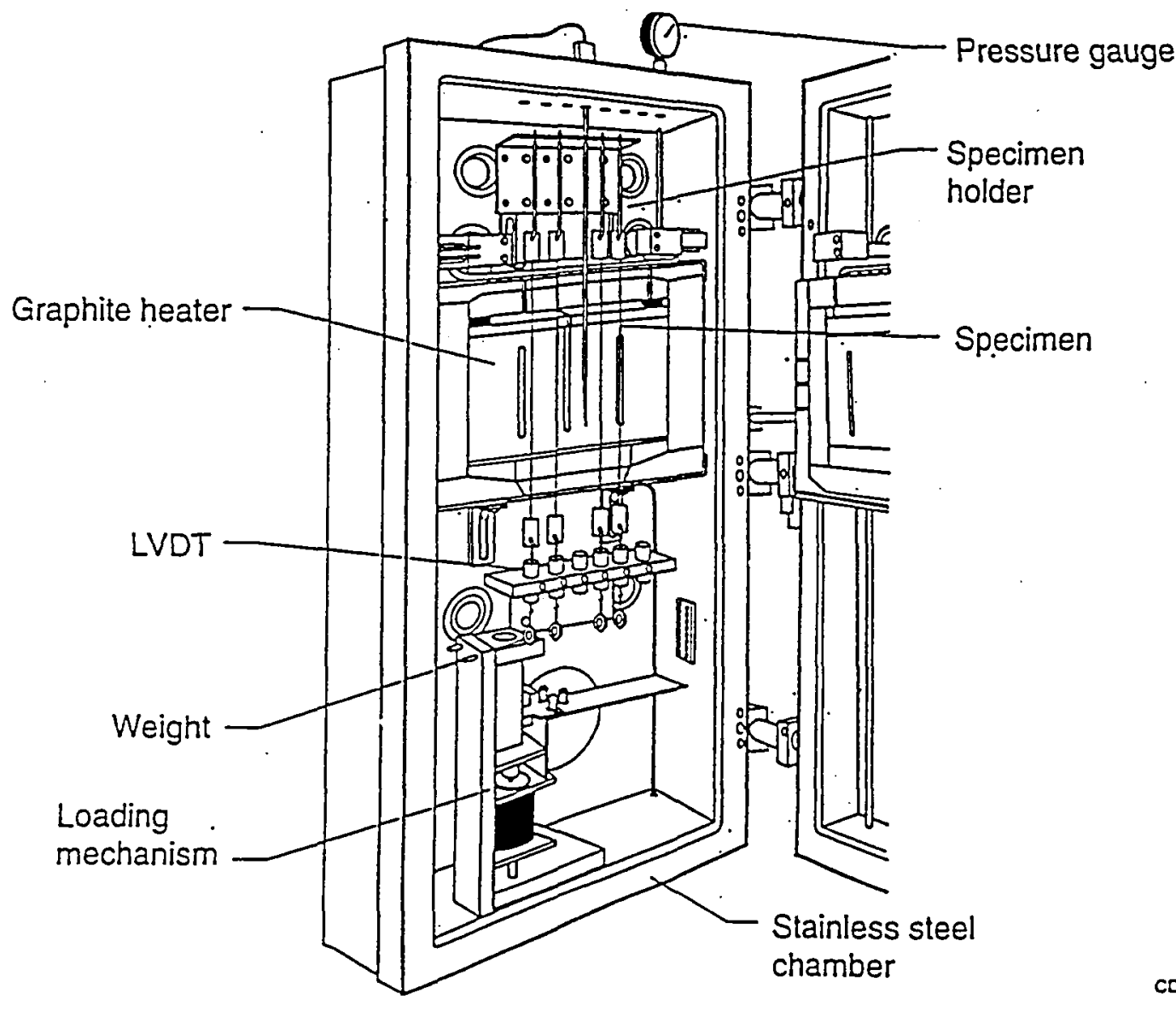

Fig. 1 Multiple Fiber (Inert/Vacuum) Creep Rig 


\section{RESULTS AND DISCUSSION}

\section{- Room Temperature Strength}

After annealing at 1500 and $1600^{\circ} \mathrm{C}$, Hi-Nicalon strength at room temperature decreased from $2800 \mathrm{MPa}$ to $1100 \mathrm{MPa}$, as shown in Fig.

2. The Weibull modulus remained unchanged after annealing. The surfaces were clean and shiny after thermal treatment at $1600^{\circ} \mathrm{C}$ (not shown). The reduction in room temperature strength may be caused by grain growth $[3,4]$ or by flaw growth as a result of silicon oxycarbide decomposition. The strength reductions after annealing at 1500 and $1600{ }^{\circ} \mathrm{C}$ were similar to those observed by Takeda et al [4], as shown in Fig.3. The slightly larger drop in this investigation was not clear, but may be due to different fiber lots.

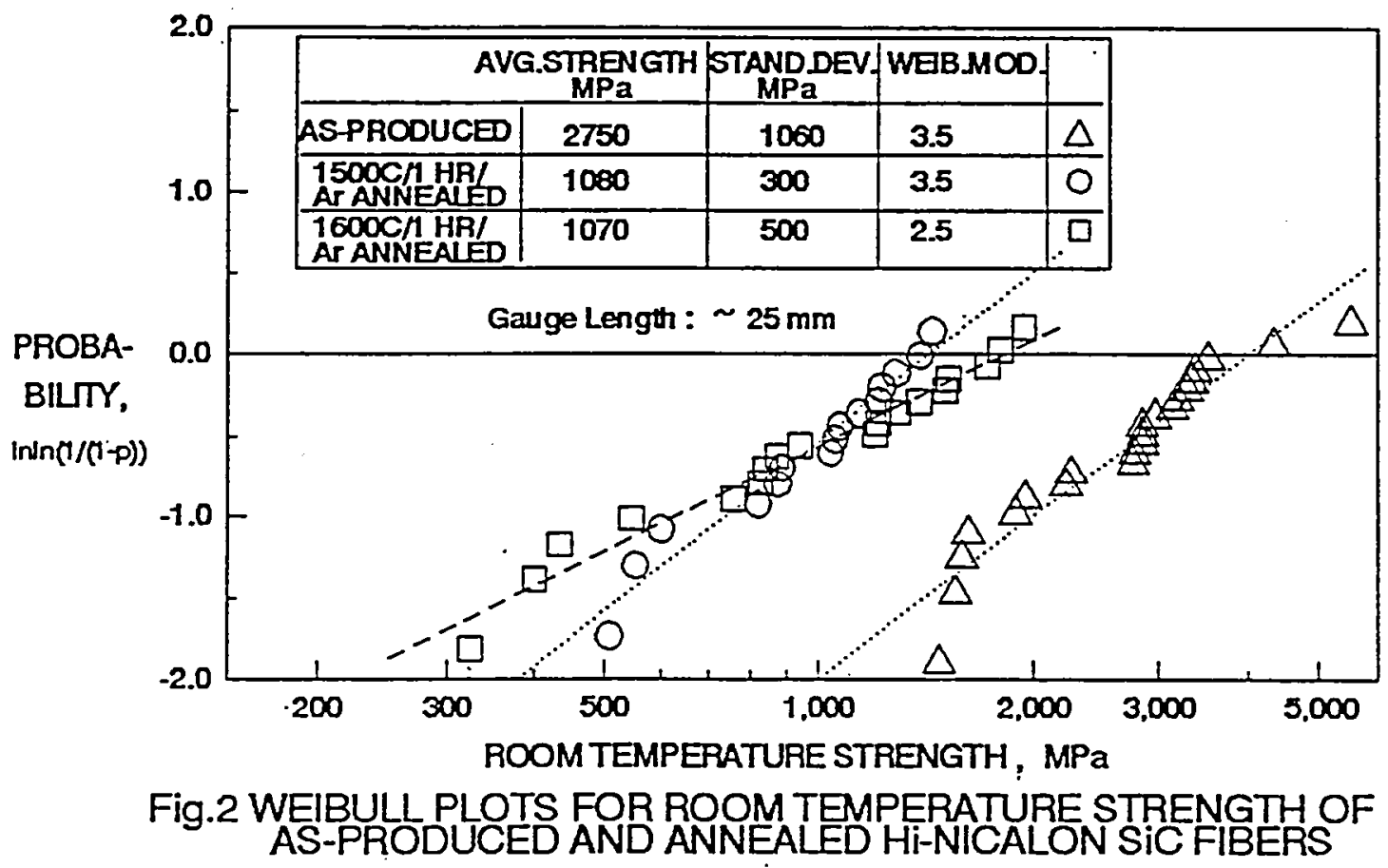

\section{- Creep}

Representative creep curves are shown in Fig. 4 for as-received and annealed Hi-Nicalon fibers tested at $1400^{\circ} \mathrm{C}$ and $140 \mathrm{MPa}$ in argon (Fig. 4 a) and in air (Fig. 4 b). For annealing at $1500^{\circ} \mathrm{C}$ 


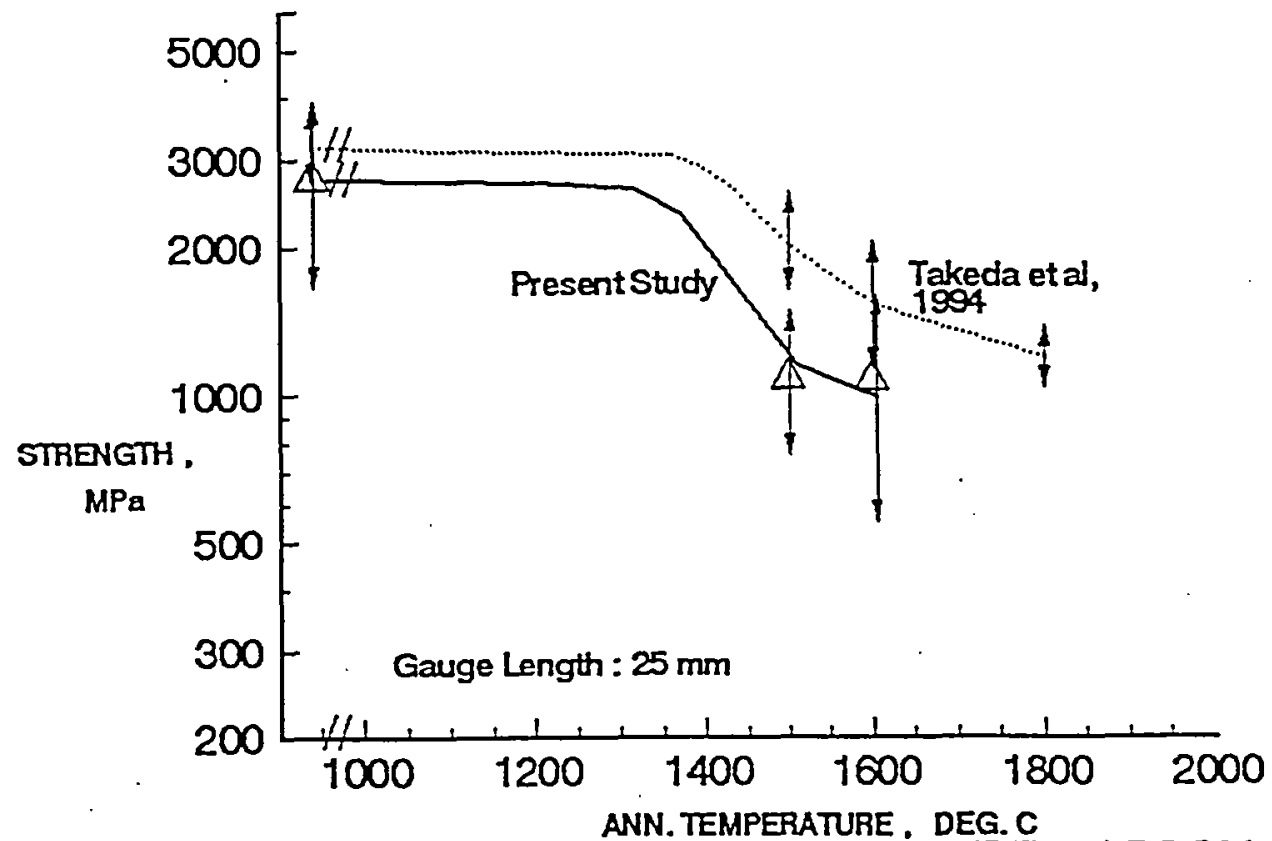

Fig.3 EFFECT OF ANNEALING TEMPERATURE ON ROOM TEMPERATURE STRENGTH OF HI-NICALON FIBERS
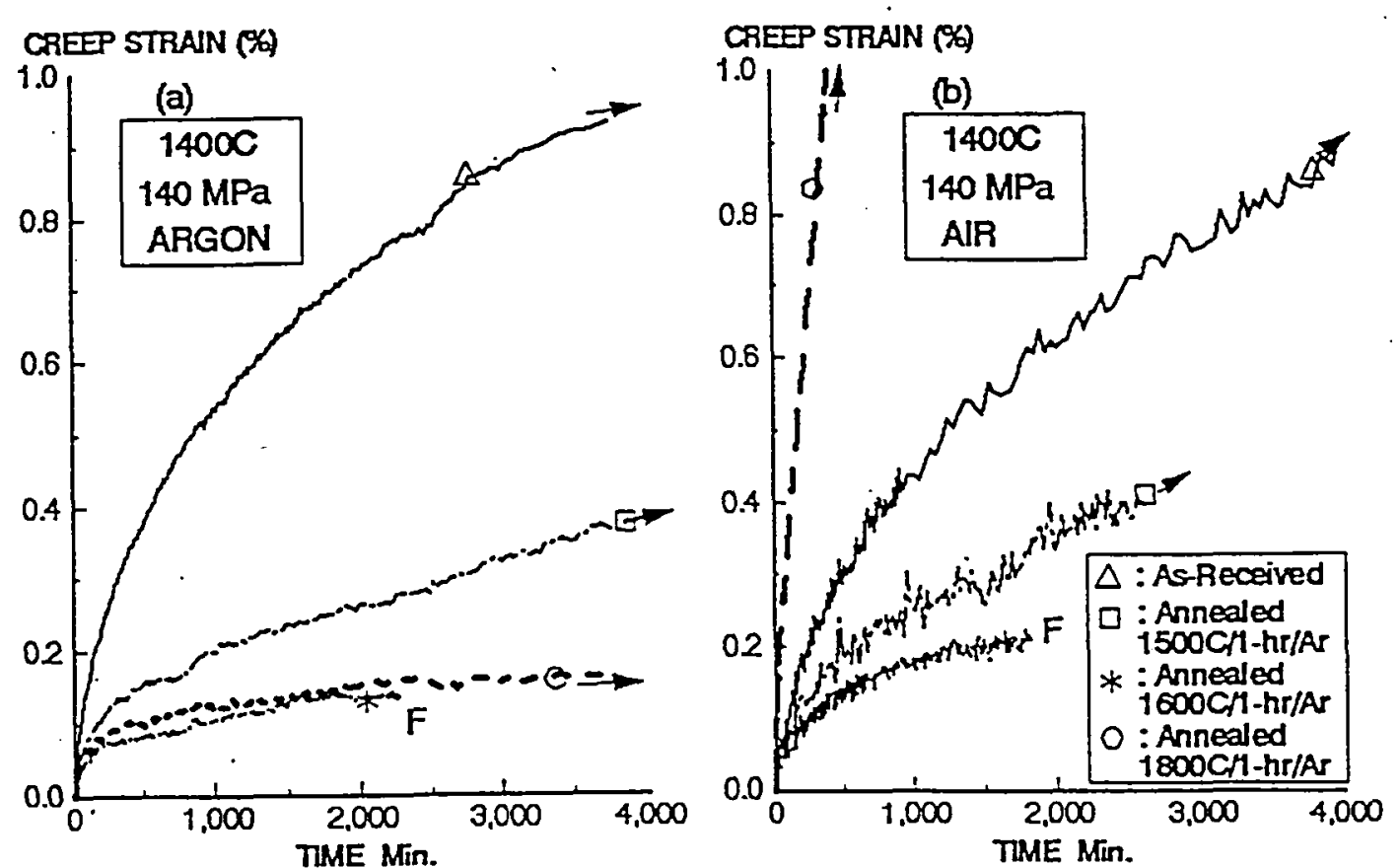

FIg. 4 REPRESENTATIVE CREEP-RUPTURE CURVES AT $1400 \mathrm{C}$ FOR AS-RECENED AND 1 - HR ARGON ANNEALED Hi-NICALON 
and above, creep in argon decreased significantly and leveled off for anneals from 1600 to $1800^{\circ} \mathrm{C}$. For anneals up to $1600{ }^{\circ} \mathrm{C}$, creep in air also decreased, but after the $1800^{\circ} \mathrm{C}$ anneal, creep drastically increased (failure strain of $12 \%$ at $140 \mathrm{MPa}$ ) and rupture time decreased. The drastic increase in air creep after $1800^{\circ} \mathrm{C}$ annealing was also observed at $1200^{\circ} \mathrm{C}$ (failure strain above $15 \%$ at $140 \mathrm{MPa}$ ).

A similar influence of testing environment has also been reported for reaction-bonded silicon nitride (RBSN); that is, low creep in argon and more creep at lower temperatures in air than at higher temperatures $[7,8]$. This was related to the open porosity of the RBSN and the formation of internal $\mathrm{SiO}_{2}$. It is believed that the $\mathrm{Hi}$-Nicalon creep increase in air may also be caused by open porosity, perhaps formed with annealing temperatures above 1600 ${ }^{\circ} \mathrm{C}$. Porosity could be formed by decomposition of the small amount of the silicon-oxycarbide phase or by densification and restructuring of the free carbon. This porosity effect may be enhanced during air creep testing by oxygen penetration into the fiber and removal of the free carbon. This, in turn, could allow easier internal oxidation of the remaining $\mathrm{SiC}$ and enhanced creep by $\mathrm{SiO}_{2}$ formation. The decrease in creep observed for anneals up to $1500^{\circ} \mathrm{C}$ is probably related to $\mathrm{SiC}$ grain growth or to carbon restructuring with little open porosity formation. Similar creep resistance improvement in argon was reported by Bodet et al [3] after $1-\mathrm{hr} 1600^{\circ} \mathrm{C}$ anneals.

\section{- Creep and Rupture Strength}

By measuring creep and rupture time at many stresses, the effects of annealing on Hi-Nicalon creep strength and rupture strength were also determined. The creep strength results for reaching 0.1 $\%$ in 10 hours are shown in Fig. 5 as a function of annealing temperature, test environment, and test temperature. At 1200 and $1400^{\circ} \mathrm{C}$, the $0.1 \%$ creep strength in argon steadily increased until anneals up to $1800^{\circ} \mathrm{C}$; whereas the creep strength in air maximized after anneals at $1500^{\circ} \mathrm{C}$ and then decreased dramatically. Comparatively the creep strength degradation in air for anneals above $1500^{\circ} \mathrm{C}$ was greater at $1200^{\circ} \mathrm{C}$ than at $1400^{\circ} \mathrm{C}$. This may be explained by the rapid formation of a silica layer overcoating of the fiber at $1400^{\circ} \mathrm{C}$ which inhibited oxygen 
ingress into the fiber.

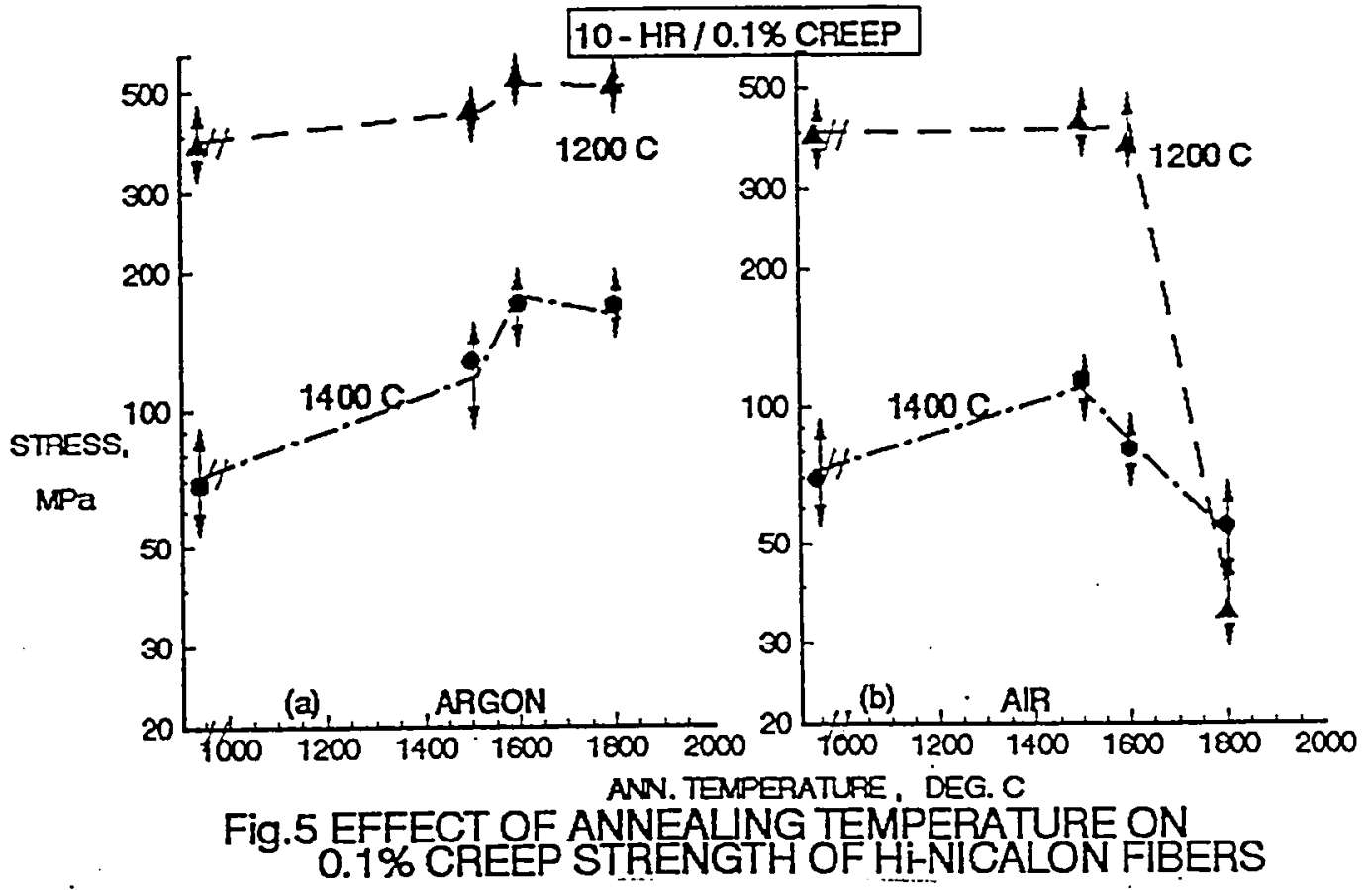

The $10 \mathrm{hr}$ rupture strength was also determined at 1200 and $1400^{\circ} \mathrm{C}$ as a function of annealing temperature and test environment. The results are shown in Figs. $6 a$ and $6 b$ for argon and air, respectively. The rupture strength was not degraded significantly after anneals at $1500{ }^{\circ} \mathrm{C}$ for both air and argon test environments. Above $1600^{\circ} \mathrm{C}$ the rupture strength decreased for the air tests, while the change was not significant up to $1800^{\circ} \mathrm{C}$ for the argon tests.

SEM photomicrographs of creep-ruptured fibers annealed at $1600^{\circ} \mathrm{C}$ for $1 \mathrm{hr}$ and tested at $275 \mathrm{MPa}$ and $1400^{\circ} \mathrm{C}$ for ${ }^{-} 20 \mathrm{hrs}$ are shown in Fig. 7. The surface of the air tested fiber was fully coated by a silica layer, while that of argon tested fiber indicated the formation of ridges which may be related to the inter-connected porosity formed during annealing. The apparent damage on the fracture surface edge in the air tested specimen may be formed because of silica layer at the fiber surface, often reported as oxidation pitting. 


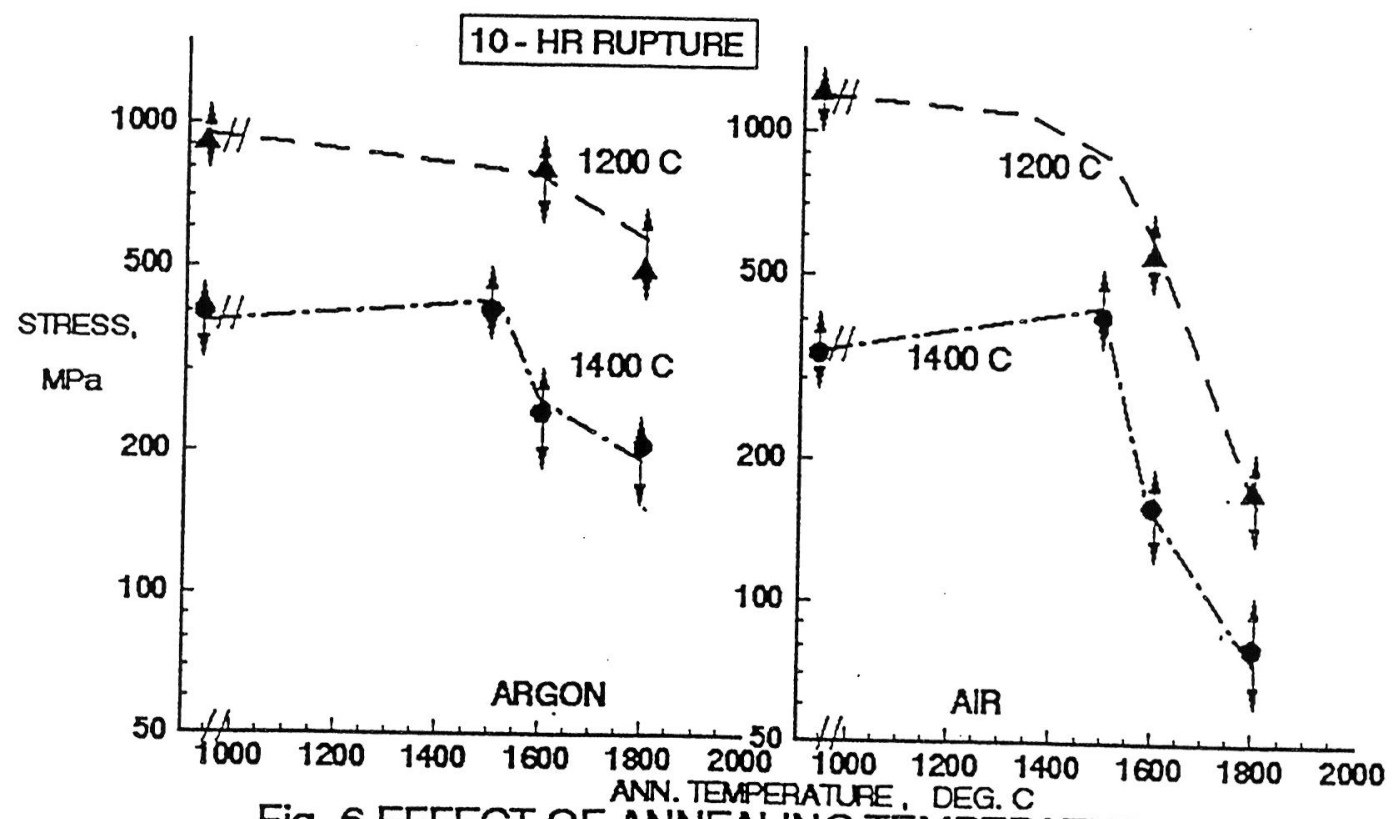

Fig. 6 EFFECT OF ANNEALING TEMMPERATURE ON RUPTURE STRENGTH OF Hi-NICALON FIBERS
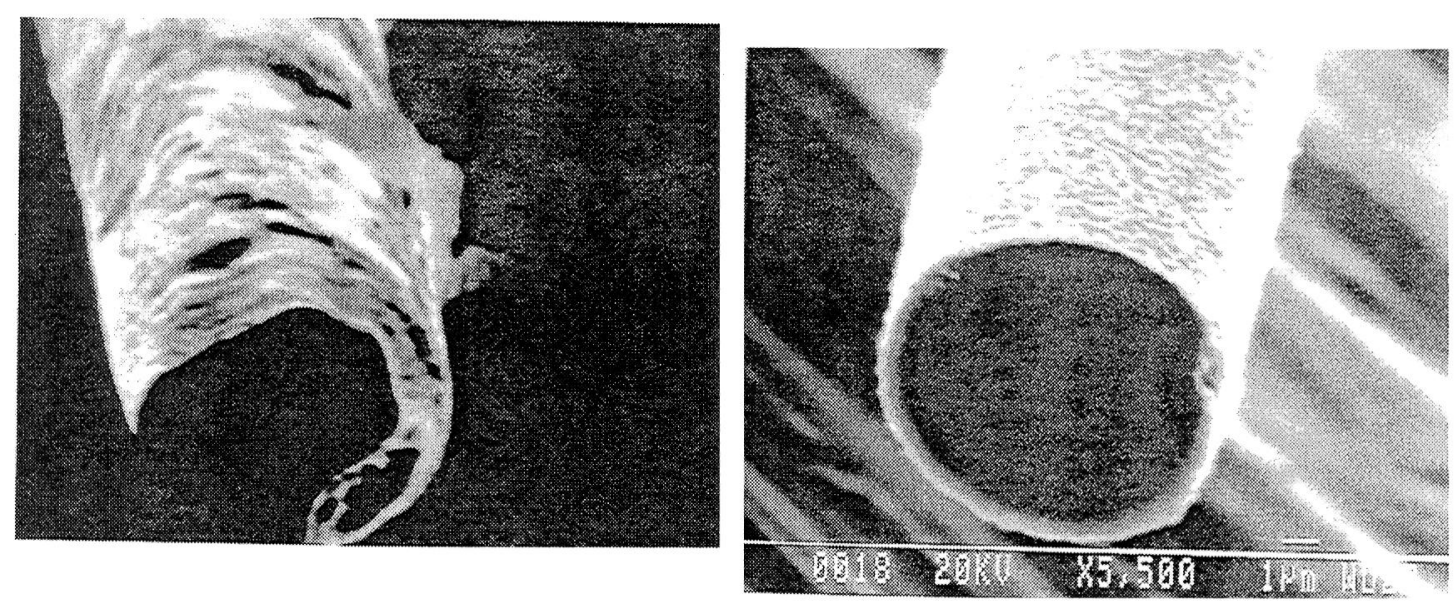

ARGON CREEP TESTED (1400 C/275 MPa/20 hr)

AIR CREEP TESTED

(1400 C/275 MPa/20 hr)

Fig. 7 SEM PHOTOMICROGRAPHS OF CREPT AND RUPTURED Hi-NICALON FIBERS, ANNEALED AT $1600^{\circ} \mathrm{C}$ 


\section{CONCLUSIONS}

For Hi-Nicalon fibers, the results of this study indicate that short-time thermal exposures from 1200 to $1500^{\circ} \mathrm{C}$ can improve fiber creep strength in argon or air, but may degrade low temperature tensile strength. This suggests that if improved high temperature structural performance is required, CMC processing conditions up to $1500^{\circ} \mathrm{C}$ can be used. Alternatively low temperature CMC fabrication conditions could include a short-term post-processing thermal treatment to ${ }^{-} 1400^{\circ} \mathrm{C}$.

For thermal exposure above $1500{ }^{\circ} \mathrm{C}$, the Hi-Nicalon creep and rupture strength degrade significantly in air tests. The large decrease in $1200^{\circ} \mathrm{C}$ creep resistance may be related to open porosity formation during the thermal exposure, carbon removal during testing in air, and $\mathrm{SiO}_{2}$ formation in grain boundaries. Reduced degradation effects at $1400^{\circ} \mathrm{C}$ may be related to the formation of a protective silica overcoating.

\section{REFERENCES}

1.M.Takeda, Y.Imai, H.Ichkawa, T.Ishkawa, N.Kasai, T.Seguchi, and K.Okamura: "Thermomechanical Analysis of the Low Oxygen Silicon Carbide Fibers Derived from Polycarbosilane", Ceramic

Eng. Sci. Proc., 14 (7-8), (1993), 540-547

2.H.M.Yun, J.C.Goldsby, and J.A.DiCarlo: "Tensile Creep and Stress-Rupture Behavior of Polymer Derived SiC Fibers", NASA TM 106692, will be published "Advances in Ceramic-Matrix Composites II", edited by J.P. Singh and Narottom P. Bansal, published by The American Ceramic Society, (1994), 17-22.

3.R.Bodet, X.Bourat, J.Lamon, and R.Naslain: "Tensile Creep Behavior of a Silicon Carbide-Based Fiber with a Low Oxygen Content", PhD Thesis, Domaine Universitaire, France, 1993 4.M.Takeda, J.Sakamoto, Y.Imai, H.Ichkawa, and T.Ishkawa: "Properties of Stoichiometric Silicon Carbide Fiber Derived from Polycarbosilane", Ceramic Eng. Sci. Proc., 15 (7-8), (1994), 133-141

5.J.A.DiCarlo, H.M.Yun, G.N.Morscher, and J.C.Goldsby: "Tensile Creep-Rupture Modeling of SiC Fibers", NASA CP 10146, Vol.III, 
(1994), 761-769

6.H.M.Yun and J.C.Goldsby: "Tensile Creep Behavior of

Polycrystalline Alumina Fibers", NASA TM 106269, (1993)

7.R.T.Bhatt: Private Communication, (1994)

8.G.Gratwohl and F.ThÜmmler: "Creep of Reaction Bonded Silicon Nitride", "Ceramics for High Performance Applications - II", edited by J.J.Burke, E.N.Lenoe, and R.N.Katz, published by the Metals and Ceramics Information Center, Columbus, Ohio, (1977), 573-591. 
Public reporting burden for this collection of information is estimated to average 1 hour per response, including the time for reviewing instructions, searching existing data sources, gathering and mainaining the data needed, and completing and reviewing the collection of information. Send comments regarding this burden estimate or any other aspect of this gathering and maintaining the ding seeded, ans lop reducing this burden, 10 Washington Headquarters Services, Directorate for Information Operations and Reports, 1215 Jefferson Davis Highway, Suite 1204, Arlington. VA 22202-4302, and to the Ottice of Management and Budget, Papenwork Reduction Project (0704-0183), Washington. DC 20503.

\begin{tabular}{|l|l|l}
\hline 1. AGENCY USE ONLY (Leave $b l a n k$ ) & $\begin{array}{c}\text { 2. REPORT DATE } \\
\text { October } 1995\end{array}$ & $\begin{array}{r}\text { 3. REPORT TYPE AND DATES COVERED } \\
\text { Technical Memorandum }\end{array}$
\end{tabular}

\section{TITLE AND SUBTTILE}

Effects of Thermal Treatment on Tensile Creep and Stress-Rupture Behavior of Hi-Nicalon SiC Fibers

6. AUTHOR(S)

H.M. Yun, J.C. Goldsby, and J.A. DiCarlo

7. PERFORMING ORGANIZATION NAME(S) AND ADDRESS(ES)

National Aeronautics and Space Administration

Lewis Research Center

Cleveland, Ohio 44135-3191

9. SPONSORING/MONITORING AGENCY NAME(S) AND ADDRESS(ES)

National Aeronautics and Space Administration

Washington, D.C. 20546-0001
5. FUNDING NUMBERS

WU-537-04-20
8. PERFORMING ORGANIZATION REPORT NUMBER

E-9965

11. SUPPLEMENTARY NOTES

Prepared for the 19th Annual Conference on Composites, Advanced Ceramics, Materials and Structures sponsored by the American Ceramic Society, Cocoa Beach, Florida, January 8-12, 1995. H.M. Yun, NASA Resident Research Associate at Lewis Research Center; J.C. Goldsby and J.A. DiCarlo, NASA Lewis Research Center. Responsible person, H.M. Yun, organization code 5120, (216) 433-6089.

12a. DISTRIBUTIONAVAILABILITY STATEMENT

12b. DISTRIBUTION CODE

Unclassified -Unlimited

Subject Category 24

This publication is available from the NASA Center for Aerospace Information, (301) 621-0390.

13. ABSTRACT (Maximum 200 words)

Tensile creep and stress-rupture studies were conducted on Hi-Nicalon SiC fibers at 1200 and $1400^{\circ} \mathrm{C}$ in argon and air. Examined were as-received fibers as well as fibers annealed from 1400 to $1800^{\circ} \mathrm{C}$ for 1 hour in argon before testing. The creep and rupture results for these annealed fibers were compared to those of the as-received fibers to determine the effects of annealing temperature, test temperature, and test environment. Argon anneals up to $1500^{\circ} \mathrm{C}$ degrade room temperature strength of $\mathrm{Hi}-\mathrm{Nicalon}$ fibers, but improve fiber creep resistance in argon or air by as much as $100 \%$ with no significant degradation in rupture strength. Argon anneals above $1500^{\circ} \mathrm{C}$ continue to improve fiber creep resistance when tested in argon, but significantly degrade creep resistance and rupture strength when tested in air. Decrease in creep resistance in air is greater at $1200^{\circ} \mathrm{C}$ than at $1400^{\circ} \mathrm{C}$. Mechanisms are suggested for the observed behavior.

14. SUBJECT TERMS

Hi-Nicalon; -SiC; Creep; Stress-rupture annealing; Activation energy; Creep exponent 15. NUMBER OF PAGES 12 16. PRICE CODE $\mathrm{A03}$

17. SECURTY CLASSIFICATION
OF REPORT
Unclassified

18. SECURTYY CLASSIFICATION
OF THIS PAGE
Unclassified
19. SECURITY CLASSIFICATION OF ABSTRACT

20. LIMTTATION OF ABSTRACT 